\title{
Volatile Emissions and Relative Attraction of the Fungal Symbionts of Tea Shot Hole Borer (Coleoptera: Curculionidae) ${ }^{\dagger}$
}

\author{
Paul E. Kendra ${ }^{1, *(\mathbb{D}}$, Nurhayat Tabanca ${ }^{1} \mathbb{D}$, Luisa F. Cruz ${ }^{2}$, Octavio Menocal ${ }^{2}$, Elena Q. Schnell ${ }^{1}$ \\ and Daniel Carrillo 2 (D) \\ 1 United States Department of Agriculture, Agricultural Research Service, Subtropical Horticulture Research \\ Station, Miami, FL 33158, USA; nurhayat.tabanca@usda.gov (N.T.); elena.schnell@usda.gov (E.Q.S.) \\ 2 Tropical Research and Education Center, University of Florida, Homestead, FL 33031, USA; \\ luisafcruz@ufl.edu (L.F.C.); omenocal18@ufl.edu (O.M.); dancar@ufl.edu (D.C.) \\ * Correspondence: paul.kendra@usda.gov \\ + This work was produced by US government employees and is in the public domain in the US.
}

check for updates

Citation: Kendra, P.E.; Tabanca, N.; Cruz, L.F.; Menocal, O.; Schnell, E.Q.; Carrillo, D. Volatile Emissions and Relative Attraction of the Fungal Symbionts of Tea Shot Hole Borer (Coleoptera: Curculionidae).

Biomolecules 2022, 12, 97.

https: / / doi.org/10.3390/

biom12010097

Academic Editors: Maroula Kokotou, Petros Tarantilis and Christos Pappas

Received: 21 December 2021

Accepted: 5 January 2022

Published: 7 January 2022

Publisher's Note: MDPI stays neutra with regard to jurisdictional claims in published maps and institutional affiliations.

Copyright: (C) 2022 by the US government employees and is in the public domain in the US Licensee MDPI, Basel, Switzerland. This article is an open access article distributed under the terms and conditions of the Creative Commons Attribution (CC BY) license (https:// creativecommons.org/licenses/by/ $4.0 /)$.
Abstract: Euwallacea perbrevis is an ambrosia beetle that vectors fungal pathogens causing Fusarium dieback in Florida avocado trees. Current monitoring lures contain quercivorol, a fungus-produced volatile, but the exact attractant is unknown since lures contain a mixture of $p$-menth-2-en-1-ol isomers and both $\alpha$ - and $\beta$-phellandrene. This study used pure cultures of six symbiotic fungi isolated from E. perbrevis to document volatile emissions and determine the relative attraction of symbionts in binary choice assays. In a comparative test, headspace solid-phase microextraction followed by gas chromatography-mass spectroscopy was used to identify and quantify emissions from 3-week-old cultures. In a temporal study, Super-Q collection followed by gas chromatography-flame ionization detection was used to measure cis- and trans-p-menth-2-en-1-ol emissions for three months. A total of 15 compounds were detected, with monoterpene hydrocarbons and oxygenated monoterpenoids predominating. Only trans-p-menth-2-en-1-ol was common to all six symbionts. Peak levels of both isomers were observed at day 7 , then gradually declined over a 90 day period. In choice tests, avocado sawdust disks inoculated with Fusarium sp. nov. were the most attractive. This symbiont produced only two volatiles, trans- $p$-menth-2-en-1-ol and limonene. The combined results indicate that trans- $p$ menth-2-en-1-ol is the primary female attractant emitted from symbiotic fungi, but limonene may be a secondary attractant of E. perbrevis.

Keywords: ambrosia beetles; chemical ecology; Euwallacea perbrevis; Fusarium dieback; invasive species; $p$-menth-2-en-1-ol; quercivorol; symbiosis

\section{Introduction}

Shot hole borers in the genus Euwallacea (Coleoptera: Curculionidae: Scolytinae) are Asian ambrosia beetles that comprise a cryptic species complex newly invasive in the continental United States and in other countries. Species established in the USA include the tea shot hole borer (E. perbrevis Schedl) in Florida, and the polyphagous shot hole borer (E. fornicatus Eichhoff) and Kuroshio shot hole borer (E. kuroshio Gomez and Hulcr) in California [1]. Typical of ambrosia beetles, females are wood borers that colonize host trees in which they cultivate symbiotic fungi as a nutritional source for larvae and adults [2]. The exotic fungi vectored by Euwallacea spp. are phytopathogenic and induce Fusarium dieback, a destructive vascular disease of avocado, woody ornamentals, and numerous native American trees [3,4].

Euwallacea perbrevis in Florida (referred to as E. nr. fornicatus in previous published reports [4,5] prior to the taxonomic revision by Smith et al. [1]) escalated in pest status in 2016 when extensive infestations were detected throughout the commercial avocado production area of Miami-Dade County [4]. Although tea [Camellia sinensis (L.) Kuntz] is 
commonly attacked in Asia [6], avocado (Persea americana Mill.) appears to be the preferred host in Florida [4,5], but colonization of other fruit trees and natives has been observed [7]. Avocado is an important agricultural commodity in south Florida, with a production value of \$23.6 million for the 2019-2020 season [8]. The prevalence of Fusarium dieback presents additional challenges to Florida growers, who are already experiencing significant losses due to laurel wilt, a lethal vascular disease of the Lauraceae, including avocado. Laurel wilt is caused by Raffaelea lauricola T. C. Harr., Fraedrich and Aghayeva, the primary fungal symbiont of redbay ambrosia beetle, Xyleborus glabratus Eichhoff $[9,10]$; however, this symbiont has since transferred laterally to multiple species of ambrosia beetle in Florida, which now function as additional vectors [11,12].

Field monitoring of E. perbrevis populations was first achieved using lures containing quercivorol, a food-based attractant emitted by symbiotic fungi [13]. Lures were deployed in either Lindgren funnel traps or sticky panel traps $[4,5,14]$. Subsequent studies showed that the $\alpha$-copaene lure developed for redbay ambrosia beetle [15] also improved captures of E. perbrevis when combined with quercivorol $[5,16,17]$. Analysis of the commercial quercivorol lure indicated that it contained four enantiomers of $p$-menth-2-en-1-ol as well as $\alpha$ - and $\beta$-phellandrene; the percent composition consisted of two trans-isomers: $48.12 \%$ $(1 R, 4 S)$ - $p$-menth-2-en-1-ol and 39.97\% (1S,4R)-p-menth-2-en-1-ol, two cis-isomers: 4.95\% $(1 R, 4 R)$ - $p$-menth-2-en-1-ol and 3.98\% (1S,4S)-p-menth-2-en-1-ol, 1.57\% $\beta$-phellandrene, and $1.42 \% \alpha$-phellandrene [16]. The common name 'quercivorol' refers only to $(1 S, 4 R)-p$-menth2-en-1-ol [18], which is not the predominant component in the lure, so it is not clear which enantiomer(s) is/are attractive to E. perbrevis. It has also not been determined which fungal symbionts emit volatiles attractive to the beetle, warranting further investigation of the chemical ecology underpinning the interaction of E. perbrevis and its fungal symbionts.

In this study, we (1) prepared pure laboratory cultures of six fungal symbionts isolated from E. perbrevis, (2) identified and quantified the chemical emissions from each symbiont using volatile collections by headspace solid-phase microextraction (HS-SPME) coupled with gas chromatography-mass spectroscopy (GC-MS), (3) documented the pattern of Super-Q collected emissions of cis- and trans- $p$-menth-2-en-1-ol for 90 days by gas chromatography-flame ionization detection (GC-FID), and confirmed by GC-MS, from a symbiont that emitted both isomers, and (4) conducted binary choice bioassays with female E. perbrevis to determine relative attraction to symbionts.

\section{Materials and Methods}

\subsection{Fungal Cultures}

Six E. perbrevis fungal associates-Fusarium sp. AF-6 (AF-6), Fusarium sp. AF-8 (AF-8), Fusarium sp. nov., Graphium sp., Acremonium sp., and Acremonium murorum-were obtained from stock cultures isolated and identified at the Tropical Fruit Entomology Laboratory, University of Florida, Tropical Research and Education Center (TREC), Homestead, FL, USA. Sequences of the strains used in this study were deposited into GenBank (AF-6: translation elongation factor 1- $\alpha$ (EF1- $\alpha)$-MZ265351, DNA-directed RNA polymerase subunit 1 (RBP1)-MZ265354, second-largest subunit of RNA polymerase (RBP2)-MZ265357; AF-8: EF1- $\alpha-M Z 265350$, RBP1-MZ265353, RBP2-MZ265356; Fusarium sp. nov: EF1- $\alpha-$ MZ265349, RPB1-MZ265352, RPB2-MZ265355; Graphium sp.: 28S large ribosomal subunit (LSU)-MZ262759, 18S small ribosomal subunit (SSU)-MZ262756; Acremonium sp.: LSUMZ262757, SSU-MZ262754; A. murorum: LSU-MZ262757, SSU-MZ262755). Fungal strains were cultured on $100 \mathrm{~mm}($ diam $) \times 15 \mathrm{~mm}$ Petri dishes containing potato dextrose agar media (PDA) (BD, Franklin Lakes, NJ, USA) (Fisher Scientific, Waltham, MA, USA). For the bioassays, $100 \mu \mathrm{L}$ of $1 \times 10^{6}$ spores/mL suspensions of Fusarium sp. nov., AF- 8 and Graphium sp. were individually plated on $47 \mathrm{~mm}$ (diam) Petri dishes containing avocado sawdust media [19]. PDA and sawdust media plates were incubated at $25^{\circ} \mathrm{C}$. 


\subsection{Test Chemicals}

Chemical standards consisted of $\alpha$-phellandrene \#99-83-2, $\alpha$-terpinene \#99-86-5, $p$ cymene \#99-87-6, limonene \#5989-54-8, terpinen-4-ol \#20126-76-5, and $\alpha$-terpineol \#98-55-5 (purchased from Sigma-Aldrich, St. Louis, MO, USA); $\beta$-elemene \#515-13-9 and valencene \#4630-07-3 (purchased from Fluka Chemical Co., Buchs, SG, Switzerland); and cis-p-menth2-en-1-ol and trans-p-menth-2-en-1-ol mixture (commercial quercivorol lure, Product \#3402, obtained from Synergy Semiochemicals Corp., Delta, BC, Canada).

\subsection{Volatile Extraction}

Mycelial cultures on PDA Petri dishes of A. murorum, Acremonium sp., AF-6, AF-8, Fusarium sp. nov. and Graphium sp. were sampled for volatile emissions when 24-25 days old. Collection of volatile compounds was performed using a SPME fiber coated with $50 / 30 \mu \mathrm{m}$ divinylbenzene/carboxen on polydimethylsiloxane (DVB/CAR/PDMS). Each fungal culture was placed in a Pyrex cylindrical jar then sealed with plastic film and left at $25^{\circ} \mathrm{C}$ for $30 \mathrm{~min}$ for equilibration of volatiles in the headspace. After equilibration, the film was pierced with the SPME needle, and the fiber exposed to the sample headspace for $1 \mathrm{~h}$ at $25^{\circ} \mathrm{C}$. After the extraction, the fiber was immediately inserted into the injector port of the GC-MS for desorption $2 \mathrm{~min}$ in the splitless mode.

\subsection{Gas Chromatography-Mass Spectrometry Analysis}

Volatile emissions were analyzed by GC-MS Agilent 7890B GC coupled with 5977B mass selective detector (Agilent Technologies, Santa Clara, CA, USA). A DB-5 column (30 m $\times 0.25 \mathrm{~mm}$ inner diameter with $0.25 \mu \mathrm{m}$ film thickness) was used and GC oven temperature program was $60{ }^{\circ} \mathrm{C}$ for $1.3 \mathrm{~min}$, rose at $3^{\circ} \mathrm{C} / \mathrm{min}$ up to $246^{\circ} \mathrm{C}$. The injector and detector temperatures were kept at $220^{\circ} \mathrm{C}$ and $230{ }^{\circ} \mathrm{C}$. Helium was used as a carrier gas at a flow rate of $1.3 \mathrm{~mL} / \mathrm{min}$. Mass spectra were recorded at $70 \mathrm{eV}$. Mass range was $m / z 35$ to $450 \mathrm{Da}$ and the scan rate was 2.8 scans/s. Mass Hunter B.07.06 software (Agilent Technologies) was used for data acquisition and processing. Volatile compounds emitted by symbionts were identified by comparing retention times, retention indices (RI) calculated using the Van den Dool and Kratz [20] equation in relation to a homologous series of $n$-alkanes $\left(\mathrm{C}_{9}-\mathrm{C}_{21}\right)$ and libraries MassFinder [21], Adams Library [22], Flavours and Fragrances of Natural and Synthetic Compounds 3 [23], and Wiley 12/NIST 2020 [24], and in-house library "SHRS Essential Oil Constituents-DB-5" which was built up from authentic standards and components of known essential oils $[5,7,16]$. Results expressed as the relative percentage of each compound peak area to the total GC-MS peak area. Compounds released from Petri plates without fungal culture and siloxanes in procedural blanks as background contamination produced by SPME fiber were subtracted. All sample preparations and analyses were independently performed in triplicate.

\subsection{Collection and Quantification of p-Menth-2-en-1-ols}

Volatile emissions of cis-p-menth-2-en-1-ol and trans- $p$-menth-2-en-1-ol from Graphium sp. cultures on PDA Petri plates (four replicates) were sampled over the course of three months every two or three days using Super-Q adsorbent (Analytical Research Systems, Gainesville, FL, USA). Cultures were stored for the duration of this study at $25{ }^{\circ} \mathrm{C}$ in an incubator (Shel lab, model SRI20PF, Sheldon Mfg. Inc., Cornelius, NC, USA). Super$Q$ volatile collections were conducted as described previously [16] but using a slightly modified version. Small oven bags (Reynolds, Richmond, VA, USA) were used for the collection of volatile emissions from each Petri plate, using two port holes to connect to the volatile collection system. Filtered air was introduced at $1 \mathrm{~L} / \mathrm{min}$ through one port hole; a Super-Q trap collector attached to a vacuum line pulling at $1 \mathrm{~L} / \mathrm{min}$ was set up on the other port hole (push-pull system). Collection of volatiles was timed for $15 \mathrm{~min}$. Volatile emissions were eluted from the Super-Q adsorbent using $200 \mu \mathrm{L}$ methylene chloride (\#7509-2, Sigma-Aldrich, St. Louis, MO, USA) and an internal standard equivalent to $5 \mu \mathrm{g}$ of 
$\mathrm{C}_{16}$ (hexadecane \#544-76-3, Sigma-Aldrich, St. Louis, MO, USA) was added to each sample prior to injection onto the GC analysis.

For quantitative analysis, samples were analyzed using a 7890B Agilent GC with a flame ionization detector (FID) and a split-splitless injector. The column was an Agilent DB-5 $30 \mathrm{~m} \times 0.25 \mathrm{~mm} \times 0.25 \mu \mathrm{m}$ (Agilent Technologies, Santa Clara, CA, USA). Injector temperature was $220^{\circ} \mathrm{C}$; split ratio was 20:1. The carrier gas was helium with a total flow of $27.2 \mathrm{~mL} / \mathrm{min}$ and a pressure of $14.4 \mathrm{psi}$. The oven temperature was programmed at $60^{\circ} \mathrm{C}$ for $1.3 \mathrm{~min}$ increasing at $3{ }^{\circ} \mathrm{C} / \mathrm{min}$ to reach a final temperature of $246{ }^{\circ} \mathrm{C}$. The FID was set to $250^{\circ} \mathrm{C}$. Extracts were quantified by GC-FID and analyzed by GC-MS for comparison purposes only.

\subsection{Experimental Insects}

Mature E. perbrevis females were obtained from laboratory colonies maintained at TREC, using rearing methods described previously by Cruz et al. [25]. Briefly, E. perbrevis females were excavated from avocado logs collected from an orchard in Miami-Dade County, Florida, USA ( $\left.25^{\circ} 31^{\prime} 31^{\prime \prime} \mathrm{N}, 80^{\circ} 29^{\prime} 7^{\prime \prime} \mathrm{W}\right)$. An avocado sawdust rearing medium was prepared and poured into $50 \mathrm{~mL}$ conical centrifuge tubes [19]. Females were surfacedisinfested with $70 \%(v / v)$ ethanol for $5-7 \mathrm{~s}$ and individually placed into the tubes. Rearing tubes were capped with lids fitted with a $1 \mathrm{~cm}$ metallic screen opening for airflow and maintained at $25{ }^{\circ} \mathrm{C}$ and $75 \%$ relative humidity, with a 16:8 L:D photoperiod.

\subsection{Laboratory Bioassays}

Dual-choice bioassays were conducted in shallow plastic containers $(21 \mathrm{~cm}$ long $\times$ $15 \mathrm{~cm}$ wide $\times 8 \mathrm{~cm}$ high) lined with white paper (Gordon Paper Co., Inc., Virginia Beach, VA, USA; BWKB18401000) to provide a rough surface upon which the beetles could walk, comparable to test arenas described previously [26]. Avocado sawdust disks inoculated with Fusarium sp. nov., AF-8 or Graphium sp. were placed on opposite sides of the container. A plastic vial containing six E. perbrevis females ( $\leq 7$ days post-emergence) was placed at the center of each container. After a $5 \mathrm{~min}$ acclimation period, the vial was removed to allow the females to interact with the inoculated avocado sawdust disks. The container was then covered with a fitted lid with two screened ventilation holes and kept in a walk-in-rearing room at $25{ }^{\circ} \mathrm{C}$ in complete darkness. The number of beetles on, in or next to each avocado sawdust disk was recorded at one time point after $12 \mathrm{~h}$. Beetles that did not choose a given treatment (not in, on or next to an avocado sawdust disk) were excluded from the analysis. Each combination of symbionts was replicated six times, reversing the position of the symbionts, and using new cohorts of beetles each time.

\subsection{Statistical Analysis}

The data obtained from GC-MS were subjected to multivariate analysis. Principal component analysis (PCA) was performed using XLSTAT 2021 (Addinsoft, New York, NY, USA). Pearson correlation was adopted. A hierarchical cluster analysis (HCA) was performed using JMP Pro.16.0 software (SAS Institute Inc., Cary, NC, USA) using Ward's clustering method. Regression analysis with exponential decay models was used to analyze emissions of cis- and trans-p-menth-2-en-1-ol from the Graphium sp. cultures; analysis by $t$-test was used to assess for differences in emissions of the two isomers at each sampling point (SigmaPlot 14.0, Systat Software Inc., San Jose, CA, USA). The results of the dualchoice bioassays were analyzed using a Kruskal-Wallis non-parametric test (SAS Institute Inc., Cary, NC, USA).

\section{Results and Discussion}

\subsection{Volatile Emissions of Symbionts}

SPME-GC-MS volatile compositions for individual fungal symbionts of E. perbrevis are presented as the peak area percentages in Table 1. A total of 15 compounds were detected from the emissions of the six symbionts, and the chemical structures of those 
compounds are illustrated in Figure 1. Notably, the monoterpene hydrocarbons and oxygenated monoterpenoids were the most abundant terpenoid classes emitted by the symbionts. Limonene and trans-p-menth-2-en-1-ol were the major constituents in the group of monoterpenoids in five symbionts, while aristolochene and valencene were higher in symbiont AF-8 than in Acremonium sp., AF-6 and Graphium sp. (Figure 2). Regarding the components present in the commercial quercivorol lure [16], trans-p-menth-2-en-1-ol was the only volatile detected across all six symbionts. cis-p-Menth-2-en-1-ol was detected in the emissions from Graphium sp. and both Acremonium spp. but was absent in the emissions from AF-6, AF-8, and Fusarium sp. nov. $\alpha$-Phellandrene was detected in the emissions from A. murorum and Graphium sp., while $\beta$-phellandrene was emitted from cultures of $A$. murorum, AF-8, and Graphium sp.<smiles>CC1=CCC(C(C)C)C=C1</smiles>

1<smiles>C=C(C)C1C=CC(C)(O)CC1</smiles>

7<smiles>CC1=CC=C(C(C)C)CC1</smiles>

2<smiles>CC(C)C1C=CC(C)(O)CC1</smiles>

8<smiles>Cc1ccc(C(C)C)cc1</smiles>

3<smiles>C=C(C)C1CC=C(C)CC1</smiles>

4<smiles>C=C1C=CC(C(C)C)CC1</smiles>

5<smiles>CC(C)C1C=CC(C)(O)CC1</smiles>

6<smiles>CC1=CCC(O)(C(C)C)CC1</smiles>

9<smiles>CC1=CCC(C(C)(C)O)CC1</smiles>

10<smiles>CC1=CC(O)C(C(C)C)CC1</smiles>

11<smiles>C=CC1(C)CCC(C(=C)C)CC1C(=C)C</smiles>

12<smiles>C=C(C)C1CC=C2CCCC(C)C2(C)C1</smiles>

13<smiles>C=C(C)C1CCC2=CCCC(C)C2(C)C1</smiles>

14<smiles>C=C1CCCC1(C)C1(C)CC=C(C)CC1</smiles>

Figure 1. Structure of compounds presented in Table 1.

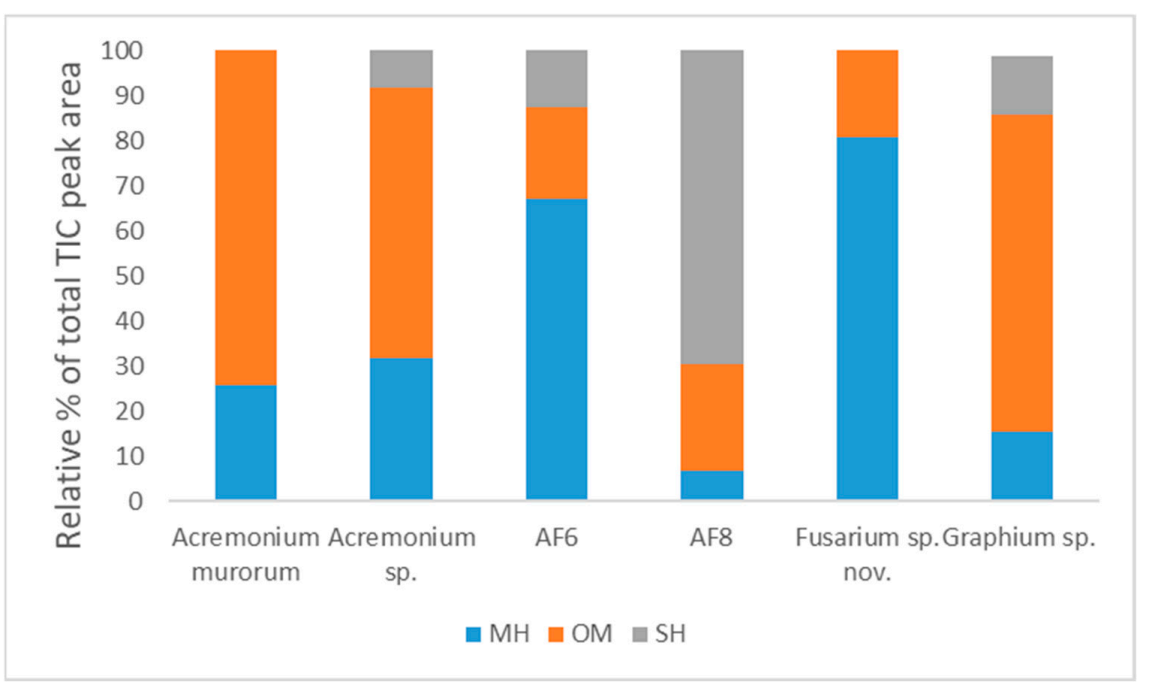

Figure 2. Percent composition of terpenoid classes in the fungal symbionts of E. perbrevis. $\mathrm{MH} \longrightarrow$ monoterpene hydrocarbons; $\mathrm{OM} \longrightarrow$ oxygenated monoterpenes; $\mathrm{SH}-$ sesquiterpene hydrocarbons. 
Table 1. Volatile emissions (mean \pm SE) produced by fungal symbionts of Euwallacea perbrevis identified by SPME-GC-MS, expressed as the peak area percentages (\%).

\begin{tabular}{|c|c|c|c|c|c|c|c|c|c|}
\hline \multirow{3}{*}{$\#$} & \multirow{3}{*}{ Compounds } & \multirow{3}{*}{$\begin{array}{l}{ }^{*} \mathrm{RI} \\
\operatorname{Exp}\end{array}$} & \multirow{3}{*}{$\begin{array}{c}* * \text { RI } \\
\text { Lit }\end{array}$} & \multicolumn{6}{|c|}{ Composition of Volatile Emissions (Relative $\% \pm$ SE) } \\
\hline & & & & & & & & & \\
\hline & & & & $\begin{array}{l}\text { Acremonium } \\
\text { murorum }\end{array}$ & $\begin{array}{l}\text { Acremonium } \\
\text { sp. }\end{array}$ & AF-6 & AF-8 & Fusarium sp. nov. & Graphium sp. \\
\hline 1 & $\alpha$-phellandrene ${ }^{a}$ & 1007 & 1002 & $9.63 \pm 2.91$ & $0.00 \pm 0.00$ & $0.00 \pm 0.00$ & $0.00 \pm 0.00$ & $0.00 \pm 0.00$ & $4.76 \pm 1.33$ \\
\hline 2 & $\alpha$-terpinene ${ }^{a}$ & 1018 & 1014 & $2.45 \pm 0.81$ & $0.00 \pm 0.00$ & $0.00 \pm 0.00$ & $0.00 \pm 0.00$ & $0.00 \pm 0.00$ & $2.03 \pm 0.69$ \\
\hline 3 & $p$-cymene ${ }^{a}$ & 1026 & 1020 & $1.59 \pm 10.67$ & $0.00 \pm 0.00$ & $0.00 \pm 0.00$ & $0.00 \pm 0.00$ & $0.00 \pm 0.00$ & $0.87 \pm 0.58$ \\
\hline 4 & Limonene $^{\mathrm{a}}$ & 1029 & 1024 & $0.00 \pm 0.00$ & $31.81 \pm 7.66$ & $66.96 \pm 3.54$ & $0.00 \pm 0.00$ & $80.61 \pm 6.76$ & $0.00 \pm 0.00$ \\
\hline 5 & $\beta$-phellandrene ${ }^{b}$ & 1030 & 1025 & $12.06 \pm 3.45$ & $0.00 \pm 0.00$ & $0.00 \pm 0.00$ & $6.68 \pm 1.59$ & $0.00 \pm 0.00$ & $7.69 \pm 2.13$ \\
\hline 6 & cis- $p$-menth-2-en-1-ol a & 1131 & 1118 & $0.71 \pm 0.04$ & $20.79 \pm 5.25$ & $0.00 \pm 0.00$ & $0.00 \pm 0.00$ & $0.00 \pm 0.00$ & $40.13 \pm 4.00$ \\
\hline 7 & cis- $p$-mentha-2,8-dien-1-ol ${ }^{\mathrm{b}}$ & 1144 & 1133 & $2.16 \pm 0.25$ & $0.00 \pm 0.00$ & $0.00 \pm 0.00$ & $0.00 \pm 0.00$ & $0.00 \pm 0.00$ & $0.16 \pm 0.04$ \\
\hline 8 & trans- $p$-menth-2-en-1-ol ${ }^{\text {a }}$ & 1149 & 1136 & $71.40 \pm 6.02$ & $39.15 \pm 6.36$ & $20.38 \pm 1.83$ & $23.56 \pm 4.36$ & $19.39 \pm 6.76$ & $27.32 \pm 2.96$ \\
\hline 9 & terpinen-4-ol a & 1185 & 1174 & $0.00 \pm 0.00$ & $0.00 \pm 0.00$ & $0.00 \pm 0.00$ & $0.00 \pm 0.00$ & $0.00 \pm 0.00$ & $1.92 \pm 0.08$ \\
\hline 10 & $\alpha$-terpineol ${ }^{\mathrm{a}}$ & 1199 & 1186 & $0.00 \pm 0.00$ & $0.00 \pm 0.00$ & $0.00 \pm 0.00$ & $0.00 \pm 0.00$ & $0.00 \pm 0.00$ & $0.68 \pm 0.05$ \\
\hline 11 & trans-piperitol $^{\mathrm{b}}$ & 1203 & 1207 & $0.00 \pm 0.00$ & $0.00 \pm 0.00$ & $0.00 \pm 0.00$ & $0.00 \pm 0.00$ & $0.00 \pm 0.00$ & $0.32 \pm 0.04$ \\
\hline 12 & $\beta$-elemene ${ }^{a}$ & 1394 & 1389 & $0.00 \pm 0.00$ & $0.00 \pm 0.00$ & $0.00 \pm 0.00$ & $0.00 \pm 0.00$ & $0.00 \pm 0.00$ & $0.50 \pm 0.11$ \\
\hline 13 & Aristolochene ${ }^{b}$ & 1486 & 1496 & $0.00 \pm 0.00$ & $8.25 \pm 4.18$ & $12.65 \pm 2.00$ & $49.43 \pm 3.99$ & $0.00 \pm 0.00$ & $10.21 \pm 1.59$ \\
\hline 14 & Valencene $^{\mathrm{a}}$ & 1494 & 1496 & $0.00 \pm 0.00$ & $0.00 \pm 0.00$ & $0.00 \pm 0.00$ & $20.32 \pm 2.33$ & $0.00 \pm 0.00$ & $1.14 \pm 0.20$ \\
\hline \multirow[t]{2}{*}{15} & $\beta$-bazzanene ${ }^{a}$ & 1522 & 1519 & $0.00 \pm 0.00$ & $0.00 \pm 0.00$ & $0.00 \pm 0.00$ & $0.00 \pm 0.00$ & $0.00 \pm 0.00$ & $0.96 \pm 0.18$ \\
\hline & Total & & & $100.00 \pm 0.00$ & $100.00 \pm 0.00$ & $99.99 \pm 0.00$ & $99.99 \pm 0.00$ & $100.00 \pm 0.00$ & $98.69 \pm 0.20$ \\
\hline
\end{tabular}

* RI exp: retention indices calculated on DB-5 column; ** RI lit: retention indices from Adams Library [22] relative concentration was expressed as the peak area and data listed were the mean of three injection results \pm standard error (SE); ${ }^{a}$ compound identified using retention time of authentic standard, matching with MS libraries and comparison with reported RI; ${ }^{b}$ compound identified by matching with MS library and comparison with reported RI.

The results of principal component analysis (PCA) are indicated by the principal components (PC) score and loading plots (PCA-Biplot). The PCA of volatile components yielded three PCs with eigenvalues $\geq 1$, accounting for $97.01 \%$ of the total variance across the entire dataset. The first, second, and third PCs contributed $49.41 \%, 31.30 \%$, and $16.30 \%$ of the total variance, respectively (Table 2). Scores and loading plots of the first two PCs obtained from volatile emissions of six symbionts are presented in Figure 3. The PCA showed three different groupings: A. murorum and Graphium sp. are located separately in the upper and lower right quadrants, respectively, while Acremonium sp., AF-6, AF-8 and Fusarium sp. nov. are clustered in the lower left quadrant. Figure 3 displays the variables factor map indicating the discriminating emissions among the symbionts. Compounds 6 (cis- $p$-menth-2-en-1-ol), 9 (terpinen-4-ol), 10 ( $\alpha$-terpineol), 11 (trans-piperitol), 12 ( $\beta$ elemene) and $\mathbf{1 5}$ ( $\beta$-bazzanene) are grouped in the lower right associated with Graphium sp.; and compounds 1 ( $\alpha$-phellandrene), 2 ( $\alpha$-terpinene), 3 ( $p$-cymene), 5 ( $\beta$-phellandrene), 7 (cis-p-mentha-2,8-dien-1-ol) and 8 (trans-p-menth-2-en-1-ol) are grouped in the upper right corner associated with $A$. murorum. In contrast, compounds $\mathbf{4}$ (limonene), $\mathbf{1 3}$ (aristolochene) and 14 (valencene) are grouped in the lower left associated with Acremonium sp. and the three Fusarium species (AF-6, AF-8 and Fusarium sp. nov.). Aristolochene was first isolated from Aspergillus terreus, and the headspace profile of Penicillium roqueforti and P. digitatum cultures were found to be rich in (+)-aristolochene (up to $80 \%$ ) and valencene (11\%) [27].

A hierarchical cluster analysis (HCA) dendrogram categorized the symbionts into three main clusters (Figure 4). Cluster I and II represented A. murorum and Graphium sp., respectively. Cluster III grouped Acremonium sp., AF-6, AF-8 and Fusarium sp. nov, confirming the results from PCA. PCA and HCA results revealed that cis- $p$-menth-2-en-1-ol and trans-p-menth-2-en-1-ol are the key components for discriminating effect of symbionts. This is the first report to compare chemical profiles of the volatile emissions in the six fungal species studied. 
Table 2. Loadings, eigenvalues, and percentage of variance for the principal components (PCs) data from symbionts.

\begin{tabular}{lccccc}
\hline Compound & F1 & F2 & F3 & F4 & F5 \\
\hline $\mathbf{1}$ & 0.278 & 0.298 & -0.030 & -0.138 & 0.075 \\
$\mathbf{2}$ & 0.333 & 0.189 & -0.029 & -0.150 & 0.070 \\
$\mathbf{3}$ & 0.289 & 0.280 & -0.030 & -0.141 & 0.074 \\
$\mathbf{4}$ & -0.243 & -0.102 & -0.418 & -0.450 & -0.098 \\
$\mathbf{5}$ & 0.261 & 0.239 & 0.291 & -0.209 & -0.254 \\
$\mathbf{6}$ & 0.261 & -0.256 & -0.079 & 0.637 & -0.169 \\
$\mathbf{7}$ & 0.158 & 0.415 & -0.026 & -0.100 & 0.071 \\
$\mathbf{8}$ & 0.148 & 0.399 & -0.035 & 0.459 & -0.022 \\
$\mathbf{9}$ & 0.307 & -0.252 & -0.010 & -0.101 & 0.015 \\
$\mathbf{1 0}$ & 0.307 & -0.252 & -0.010 & -0.101 & 0.015 \\
$\mathbf{1 1}$ & 0.307 & -0.252 & -0.010 & -0.101 & 0.015 \\
$\mathbf{1 2}$ & 0.307 & -0.252 & -0.010 & -0.101 & 0.015 \\
$\mathbf{1 3}$ & -0.091 & -0.115 & 0.594 & -0.013 & 0.694 \\
$\mathbf{1 4}$ & -0.084 & -0.048 & 0.613 & -0.121 & -0.627 \\
$\mathbf{1 5}$ & 0.307 & -0.252 & -0.010 & -0.101 & 0.015 \\
Eigenvalue & 7.411 & 4.694 & 2.446 & 0.421 & 0.027 \\
$\%$ Variance & 49.407 & 31.296 & 16.309 & 2.809 & 0.179 \\
\hline
\end{tabular}

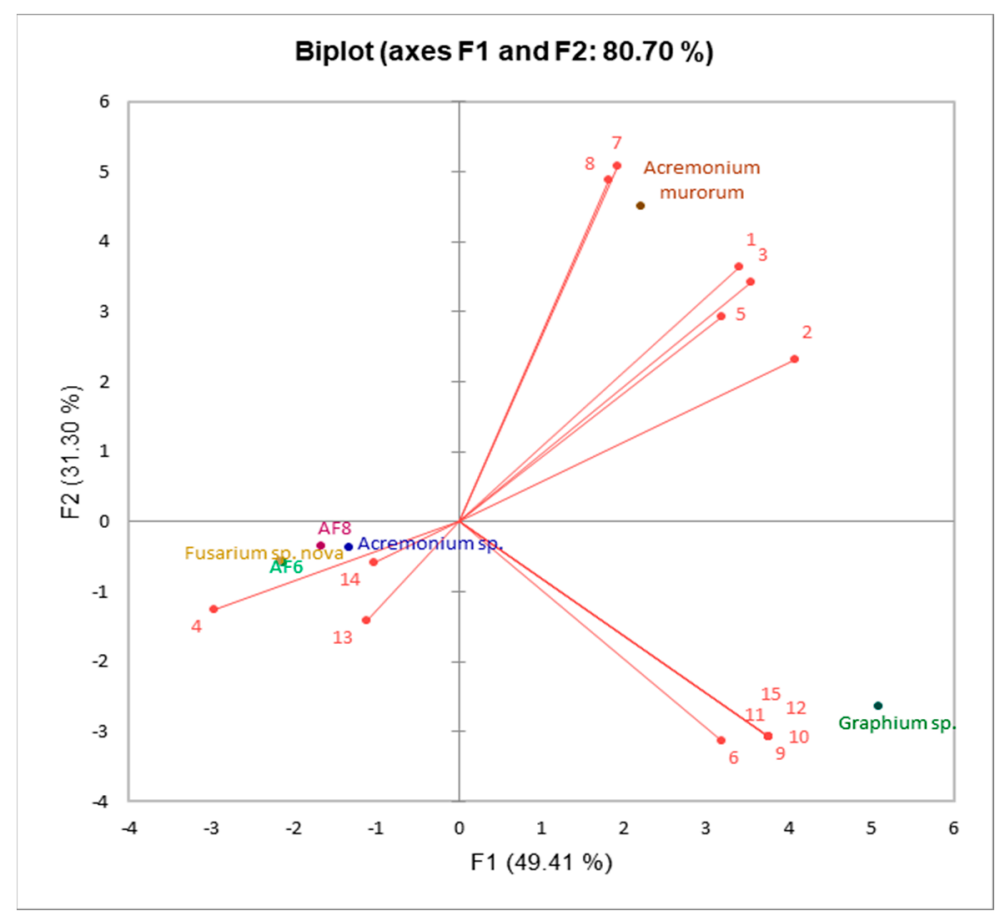

Figure 3. Principal component analysis (PCA) plot of the scores (volatile compounds emitted by symbionts) loading by dotes and loadings (symbionts) indicated by lines based on the first and second principal components. Numbers represent the compounds $\mathbf{1}$ to $\mathbf{1 5}$ in Table 1.

\section{Acremonium murorum \\ Graphium sp. \\ Acremonium sp. \\ AF6 \\ Fusarium sp. nov. AF8}

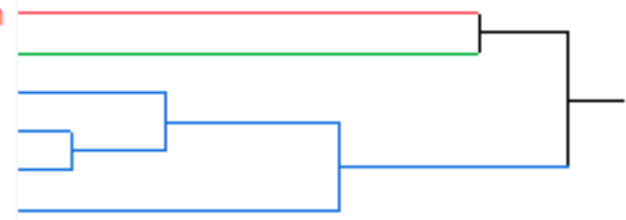

Figure 4. Hierarchical clustering (HCA) was applied using the Ward's method. Clustering between symbionts and volatile emissions was selected. 


\section{2. cis- and trans-p-Menth-2-en-1-ol Emissions from Graphium sp.}

The temporal pattern of emissions for cis- and trans-p-menth-2-en-1-ol from the Graphium sp. cultures is depicted in Figure 5. Based on our experimental design, peak emissions of both compounds were detected at day 7 (although highest levels may have occurred slightly before or after that timepoint since measurements were not recorded daily). Following that peak, emissions began to decline gradually over a period of 90 days. The decrease in emissions over time was best fit by regression with exponential decay models (cis: $y=2.59 e^{(-0.05 x)}, R^{2}=0.924$; trans: $\left.y=1.34 e^{(-0.04 x)}, R^{2}=0.927\right)$. Emissions of cis-p-menth-2-en-1-ol were higher than trans- $p$-menth-2-en-1-ol for the first 30 days, but the difference was significant only on day $10(t=11.34, \mathrm{df}=2, p=0.004)$ and day $20(t=3.24$, $\mathrm{df}=2, p=0.042)$.

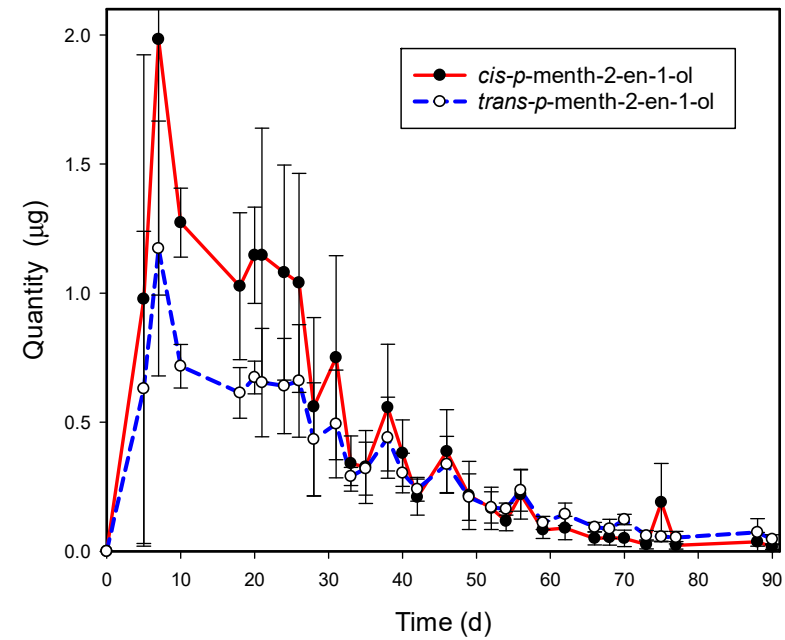

Figure 5. Emissions of cis- and trans-p-menth-2-en-1-ol quantified over time from cultures of Graphium sp. Volatiles were isolated by Super-Q collection (15 min adsorption), followed by GC-FID analysis (DB-5 column).

\subsection{Laboratory Bioassays}

Euwallacea perbrevis females were significantly more attracted to Fusarium sp. nov. than to AF-8. When given a choice between AF-8 and Graphium sp., females were significantly more attracted to AF-8, but no significant differences were observed when females were offered the Fusarium sp. nov. and Graphium sp. $(p=0.12)$ (Figure 6).
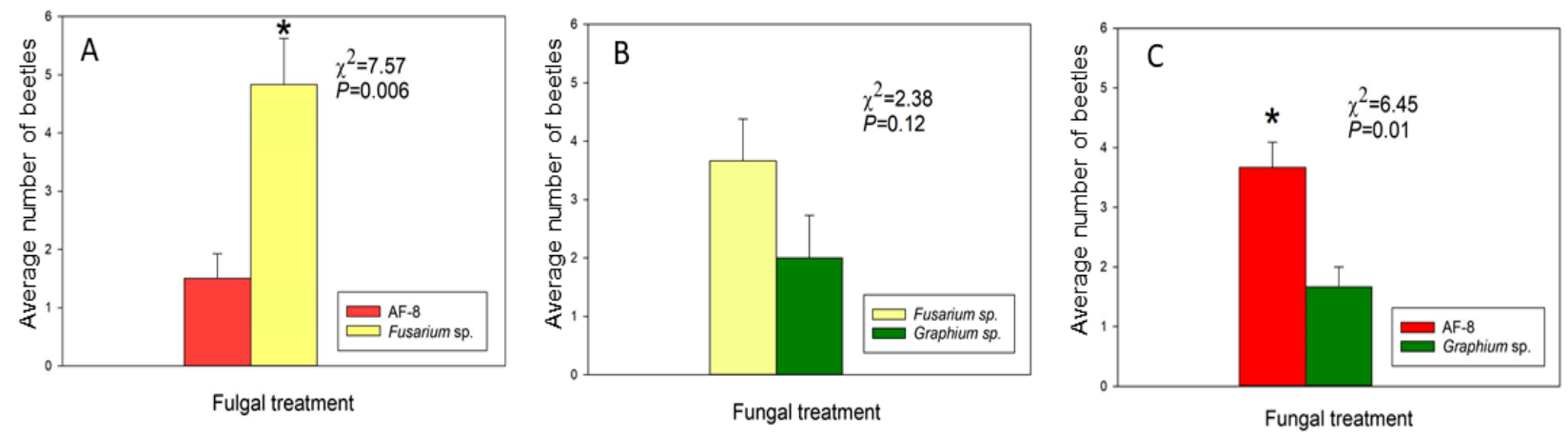

Figure 6. Avocado sawdust disks inoculated with symbiotic fungi and offered to E. perbrevis in dual-choice assays. Mean number of E. perbrevis in, on or next to the disk after $12 \mathrm{~h}$. (A) AF-8 vs. Fusarium sp. nov., (B) Fusarium sp. nov. vs. Graphium sp., (C) AF-8 vs. Graphium sp. * Indicates significant difference in attraction between the two choices $(p<0.05)$.

trans-p-Menth-2-en-1-ol, detected in the volatiles of all three test fungi, is the main component of the quercivorol lure that is attractive to E. perbrevis $[13,16]$ and other Euwal- 
lacea species [28]. The cis-isomer, also present in the quercivorol lure, was only detected in the emissions from Graphium sp. cis-p-Menth-2-en-1-ol did not increase the attraction of $E$. perbrevis to Graphium sp., suggesting that the trans-isomer is the primary attractant of E. perbrevis and possibly of other Euwallacea spp. Furthermore, trans- $p$-menth-2-en-1-ol was the only volatile compound detected in the emissions from all six symbiont cultures (Table 1). Under natural conditions, the fungal gardens of E. perbrevis would consist of mixed cultures of all six symbionts, which would emit a strong 'bouquet' of trans-p-menth-2-en-1-ol.

The two minor components in the commercial lure [16], $\alpha$ - and $\beta$-phellandrene, were also detected in the emissions from fungal symbionts. $\alpha$-Phellandrene was present in emissions from the Graphium sp. cultures, and $\beta$-phellandrene was emitted by both Graphium sp. and AF-8; however, neither compound appeared to increase attraction of female $E$. perbrevis in choice assays. (-)- $\beta$-Phellandrene is the predominant monoterpene in the phloem tissue of lodgepole pine (Pinus contorta Douglas) and a known kairomone attractant for several species of bark beetle, including the economically important pine engraver, Ips pini (Say) [29].

Graphium sp. was the least attractive symbiont despite emissions of trans- $p$-menth-2-en1-ol. This suggests that other volatiles from Graphium sp. may include potential repellents. For instance, cis- $p$-menth-2-en-1-ol and trans-piperitol are known to have repellant activity against Musca domestica L. and Haematobia irritans L. [30,31], and terpinen-4-ol has insecticidal and repellent activities against three stored-product insects: Tribolium castaneum Herbst, Lasioderma serricorne Fabricius, and Liposcelis bostrychophila Badonnel [32]. However, other volatiles produced by Graphium sp., like $p$-cymene and $\beta$-elemene, are involved in the attraction of X. glabratus to Lauraceous trees [33]. More research is needed to understand the effects of these and other volatiles from Graphium sp. as potential attractants or repellants of E. perbrevis. Identification of effective repellents would facilitate development of a pest management strategy using a 'push-pull' approach; a repellent applied to host trees would push pests away, while surrounding traps baited with attractant (i.e., the combination of trans-p-menth-2-en-1-ol and $\alpha$-copaene [5]) would reduce numbers of host-seeking females [34].

Fusarium sp. nov. was the most attractive amongst the tested fungi. Besides trans- $p$ menth-2-en-1-ol, the only other volatile detected from Fusarium sp. nov. was limonene. Therefore, limonene is likely a secondary attractant of E. perbrevis, not present in the other two symbionts. Limonene is a known attractant kairomone of another scolytine species, the white pinecone beetle, Conophthorus coniperda Schwarz [35]. Limonene is also a precursor in the synthesis of trans-p-menth-2-en-1-ol [18]. Given the structural similarities, limonene and trans- $p$-menth-2-en-1-ol may be detected by the same antennal olfactory receptors, but additional electrophysiological studies $[5,36]$ are needed to address that question.

\section{Conclusions}

Euwallacea perbrevis, a new invasive ambrosia beetle in Florida, maintains a complex association with multiple species of symbiotic fungi, some of which induce Fusarium dieback in host trees, including avocado. This study utilized pure cultures of six symbionts to identify and quantify their volatile emissions, and to determine the attractive components within those emissions. Chemical analyses indicated that trans-p-menth-2-en-1-ol was the only compound produced by all six symbionts; behavioral assays indicated that emissions of cis- $p$-menth-2-en-1-ol did not increase attraction. The most attractive symbiont, a new species of Fusarium, also emitted limonene, implicating this compound as a secondary attractant. Additional laboratory bioassays and electroantennographic analyses are needed with female E. perbrevis to assess limonene for behavioral responses and olfactory chemoreception, respectively. The results presented here may allow improving lures for field monitoring of E. perbrevis and possibly other invasive Euwallacea species.

Author Contributions: P.E.K., L.F.C., N.T., O.M., E.Q.S. and D.C. conceived, designed, and executed various components of the chemical and biological experiments. P.E.K., N.T. and D.C. performed the statistical analysis. P.E.K., L.F.C., N.T. and D.C. prepared figures and wrote the initial draft of the 
manuscript. P.E.K. revised and finalized the manuscript. All authors have read and agreed to the published version of the manuscript.

Funding: This study was supported by appropriated funds from the United States Department of Agriculture-Agricultural Research Service (USDA-ARS) (Project Number: 6038-22000-007-00D) and by a Non-Assistance Cooperative Agreement between the USDA-ARS and the University of Florida (Number: 58-6038-8-004).

Institutional Review Board Statement: Not applicable.

Informed Consent Statement: Not applicable.

Data Availability Statement: Data are contained within the article.

Acknowledgments: The authors thank Wayne Montgomery (USDA-ARS, Miami, FL, USA) for technical assistance; Kevin Cloonan (USDA-ARS, Miami, FL, USA) and Gareth Thomas (Biointeractions and Crop Protection, Rothamsted Research, Harpenden, Hertfordshire, UK) for critical reviews of an earlier version of this manuscript; and journal editors and reviewers for helpful suggestions.

Conflicts of Interest: The authors declare no conflict of interest. The mention of a trademark or proprietary product does not constitute a guarantee or warranty of the product by the USDA-ARS and does not imply its approval to the exclusion of other products that may also be suitable. USDA is an equal opportunity provider and employer.

\section{References}

1. Smith, S.M.; Gomez, D.F.; Beaver, R.A.; Hulcr, J.; Cognato, A.I. Reassessment of the species in the Euwallacea fornicatus (Coleoptera: Curculionidae: Scolytinae) complex after the rediscovery of the 'lost' type specimen. Insects 2019, 10, 261. [CrossRef] [PubMed]

2. Hulcr, J.; Stelinski, L.L. The ambrosia symbiosis: From evolutionary ecology to practical management. Ann. Rev. Entomol. 2017, 62, 285-303. [CrossRef] [PubMed]

3. Eskalen, A.; Stouthamer, R.; Lynch, S.C.; Rugman-Jones, P.F.; Twizeyimana, M.; Gonzalez, A.; Thiboult, T. Host range of Fusarium dieback and its ambrosia beetle (Coleoptera: Scolytinae) vector in southern California. Plant Dis. 2013, 97, 938-951. [CrossRef]

4. Carrillo, D.; Cruz, L.F.; Kendra, P.E.; Narvaez, T.I.; Montgomery, W.S.; Monterroso, A.; DeGrave, C.; Cooperband, M.R. Distribution, pest status, and fungal associates of Euwallacea nr. fornicatus in Florida avocado groves. Insects 2016, 7, 55. [CrossRef]

5. Kendra, P.E.; Owens, D.; Montgomery, W.S.; Narvaez, T.I.; Bauchan, G.R.; Schnell, E.Q.; Tabanca, N.; Carrillo, D. $\alpha$-Copaene is an attractant, synergistic with quercivorol, for improved detection of Euwallacea nr. fornicatus (Coleoptera: Curculionidae: Scolytinae). PLoS ONE 2017, 12, e0179416. [CrossRef]

6. Danthanarayana, W. The distribution and host-range of the shot-hole borer (Xyleborus fornicatus Eichh.) of tea. Tea Quart. 1968, 39, 61-69.

7. $\quad$ Owens, D.; Cruz, L.F.; Montgomery, W.S.; Narvaez, T.I.; Schnell, E.Q.; Tabanca, N.; Duncan, R.E.; Carrillo, D.; Kendra, P.E. Host range expansion and increasing damage potential of Euwallacea nr. fornicatus (Coleoptera: Curculionidae) in Florida. Fla. Entomol. 2018, 101, 229-236. [CrossRef]

8. United States Department of Agriculture, National Agricultural Statistics Service, Quick Stats. Available online: https:// quickstats.nass.usda.gov/ (accessed on 13 December 2021).

9. Kendra, P.E.; Montgomery, W.S.; Niogret, J.; Pruett, G.E.; Mayfield, A.E.; MacKenzie, M.; Deyrup, M.A.; Bauchan, G.R.; Ploetz, R.C.; Epsky, N.D. North American Lauraceae: Terpenoid emissions, relative attraction and boring preferences of redbay ambrosia beetle, Xyleborus glabratus (Coleoptera: Curculionidae: Scolytinae). PLoS ONE 2014, 9, e102086. [CrossRef]

10. Ploetz, R.C.; Kendra, P.E.; Choudhury, R.A.; Rollins, J.A.; Campbell, A.; Garrett, K.; Hughes, M.; Dreaden, T. Laurel wilt in natural and agricultural ecosystems: Understanding the drivers and scales of complex pathosystems. Forests 2017, 8, 48. [CrossRef]

11. Carrillo, D.; Duncan, R.E.; Ploetz, J.N.; Campbell, A.; Ploetz, R.C.; Peña, J.E. Lateral transfer of a phytopathogenic symbiont among native and exotic ambrosia beetles. Plant Pathol. 2014, 63, 54-62. [CrossRef]

12. Ploetz, R.C.; Konkol, J.L.; Narvaez, T.; Duncan, R.E.; Saucedo, R.J.; Campbell, A.; Mantilla, J.; Carrillo, D.; Kendra, P.E. Presence and prevalence of Raffaelea lauricola, cause of laurel wilt, in different species of ambrosia beetle in Florida, USA. J. Econ. Entomol. 2017, 110, 347-354. [CrossRef] [PubMed]

13. Carrillo, D.; Narvaez, T.; Cossé, A.A.; Stouthamer, R.; Cooperband, M. Attraction of Euwallacea nr. fornicatus (Coleoptera: Curculionidae: Scolytinae) to lures containing quercivorol. Fla. Entomol. 2015, 98, 780-782. [CrossRef]

14. Kendra, P.E.; Montgomery, W.S.; Narvaez, T.I.; Carrillo, D. Comparison of trap designs for detection of Euwallacea nr. fornicatus and other Scolytinae (Coleoptera: Curculionidae) that vector fungal pathogens of avocado trees in Florida. J. Econ. Entomol. 2020, 113, 980-987. [CrossRef] [PubMed]

15. Kendra, P.E.; Montgomery, W.S.; Deyrup, M.A.; Wakarchuk, D. Improved lure for redbay ambrosia beetle developed by enrichment of $\alpha$-copaene content. J. Pest Sci. 2016, 89, 427-438. [CrossRef] 
16. Owens, D.; Kendra, P.E.; Tabanca, N.; Narvaez, T.I.; Montgomery, W.S.; Schnell, E.Q.; Carrillo, D. Quantitative analysis of content and volatile emissions from $\alpha$-copaene and quercivorol lures, and longevity for attraction of Euwallacea nr. fornicatus in Florida. J. Pest Sci. 2019, 92, 237-252. [CrossRef]

17. Owens, D.; Seo, M.; Montgomery, W.S.; Rivera, M.J.; Stelinski, L.L.; Kendra, P.E. Dispersal behaviour of Euwallacea nr. fornicatus (Coleoptera: Curculionidae: Scolytinae) in avocado groves and estimation of lure sampling range. Agric. Forest Entomol. 2019, 21, 199-208. [CrossRef]

18. Kashiwagi, T.; Nakashima, T.; Tebayashi, T.; Kim, C.S. Determination of the absolute configuration of quercivorol (1S,4R)-p-menth2-en-1-ol, an aggregation pheromone of the ambrosia beetle Platypus quercivorus (Coleoptera: Platypodidae). Biosci. Biotechnol. Biochem. 2006, 70, 2544-2546. [CrossRef]

19. Menocal, O.; Cruz, L.F.; Kendra, P.E.; Crane, J.H.; Ploetz, R.C.; Carrillo, D. Rearing Xyleborus volvulus (Coleoptera: Curculionidae) on media containing sawdust from avocado or silkbay, with or without Raffaelea lauricola (Ophiostomatales: Ophiostomataceae). Environ. Entomol. 2017, 46, 1275-1283. [CrossRef]

20. Van Den Dool, H.; Kratz, P.D. A generalization of the retention index system including linear temperature programmed gas-liquid partition chromatography. J. Chromatogr. A 1963, 11, 463-471. [CrossRef]

21. MassFinder. MassFinder Software, Version 3; Hochmuth Scientific Consulting: Hamburg, Germany, 2004.

22. Adams, R.P. Identification of Essential Oil Components by Gas Chromatography/Mass Spectrometry, 4th ed.; Allured Publishing Corp: Carol Stream, IL, USA, 2017; pp. 1-804.

23. FFNSC-3. Flavors and Fragrances of Natural and Synthetic Compounds 3. In Mass Spectral Database; Scientific Instrument Services Inc.: Hoboken, NJ, USA, 2015.

24. Wiley Science Solutions. Wiley Registry 12th Edition/NIST 2020 Mass Spectral Library; Scientific Instrument Services Inc.: Ringoes, NJ, USA, 2020.

25. Cruz, L.F.; Cruz, J.C.; Carrillo, D.; Mtz-Enriquez, A.I.; Lamelas, A.; Ibarra-Juarez, L.A.; Pariona, N. In-vitro evaluation of copper nanoparticles as a potential control agent against the fungal symbionts of the invasive ambrosia beetle Euwallacea fornicatus. Crop. Prot. 2021, 143, 105564. [CrossRef]

26. Kendra, P.E.; Montgomery, W.S.; Niogret, J.; Peña, J.E.; Capinera, J.L.; Brar, G.; Epsky, N.D.; Heath, R.R. Attraction of the redbay ambrosia beetle, Xyleborus glabratus, to avocado, lychee and essential oil lures. J. Chem. Ecol. 2011, 37, 932-942. [CrossRef]

27. Demyttenaere, J.C.; Adams, A.; Van Bellaghem, K.; De Kimpe, N.; Koenig, W.A.; Tkachev, A.V. De novo production of (+)aristolocheme by sporulated surface cultures of Penicillium roqueforti. Phytochemistry 2002, 59, 597-602. [CrossRef]

28. Dodge, C.; Coolidge, J.; Cooperband, M.; Cossé, A.; Carrillo, D.; Stouthamer, R. Quercivorol as a lure for the polyphagous and Kuroshio shot hole borers, Euwallacea spp. nr. fornicatus (Coleoptera: Scolytinae), vectors of Fusarium dieback. Peer J 2017, 5 , e3656. [CrossRef] [PubMed]

29. Miller, D.R.; Borden, J.H. $\beta$-Phellandrene: Kairomone for pine engraver Ips pini (Say) (Coleoptera: Scolytidae). J. Chem. Ecol. 1990, 16, 2519-2531. [CrossRef]

30. Wimalaratne, P.D.C.; Slessor, K.N.; Borden, J.H. Isolation and identification of house fly, Musca domestica L., repellents from pepper tree, Schinus molle L. J. Chem. Ecol. 1996, 22, 49-59. [CrossRef]

31. López, A.; Castro, S.; Andina, M.J.; Ures, X.; Munguía, B.; Llabot, J.M.; Elder, H.; Dellacassa, E.; Palma, S.; Domínguez, L. Insecticidal activity of microencapsulated Schinus molle essential oil. Ind. Crops. Prod. 2014, 53, 209-216. [CrossRef]

32. Wang, Y.; Zhang, L.T.; Feng, Y.X.; Guo, S.S.; Pang, X.; Zhang, D.; Geng, Z.F.; Du, S.S. Insecticidal and repellent efficacy against stored-product insects of oxygenated monoterpenes and 2-dodecanone of the essential oil from Zanthoxylum planispinum var dintanensis. Environ. Sci. Pollut. Res. Int. 2019, 26, 24988-24997. [CrossRef]

33. Martini, X.; Hughes, M.A.; Smith, J.A.; Stelinski, L.L. Attraction of redbay ambrosia beetle, Xyleborus glabratus, to leaf volatiles of its host plants in North America. J. Chem. Ecol. 2015, 41, 613-621. [CrossRef]

34. Rivera, M.J.; Martini, X.; Conover, D.; Mafra-Neto, A.; Carrillo, D.; Stelinski, L.L. Evaluation of semiochemical based push-pull strategy for population suppression of ambrosia beetle vectors of laurel wilt disease in avocado. Sci. Rep. 2020, 10, 2670. [CrossRef]

35. Miller, D.R. Limonene: Attractant kairomone for white pine cone beetles (Coleoptera: Scolytidae) in an eastern white pine seed orchard in western North Carolina. J. Econ. Entomol. 2007, 100, 815-822. [CrossRef]

36. Kendra, P.E.; Montgomery, W.S.; Niogret, J.; Deyrup, M.A.; Guillén, L.; Epsky, N.D. Xyleborus glabratus, X. affinis, and X. ferrugineus (Coleoptera: Curculionidae: Scolytinae): Electroantennal responses to host-based attractants and temporal patterns in host-seeking flight. Environ. Entomol. 2012, 41, 1597-1605. [CrossRef] [PubMed] 